\title{
Nilai-Nilai Pendidikan Karakter dalam Kitab Al-Syamail Muhammadiyah Altirmidzi
}

\author{
Anita Aprilia ${ }^{1}$ Samsul Azwar ${ }^{2}$ M Zaid Adnan ${ }^{3}$ \\ ${ }^{1}$ Pendidikan Agama Islam, Universitas Ahmad Dahlan \\ Email: anita2008052026@webmail.uad.ac.id \\ ${ }^{2}$ Pendidikan Agama Islam, Universitas Ahmad Dahlan \\ email: Samsul1908052023@webmail.uad.ac.id \\ ${ }^{3}$ IImu al-Quran dan Tafsir, Universitas Islam Negeri Sunan Kalijaga \\ email: 19205032074@student.uin-suka.ac.id
}

\begin{abstract}
This article tries to discuss the daily personality of the Prophet, which contains good moral values that anyone can emulate. For example, how he teaches independent living, simple and caring for others. These moral values are taken from a book that is very popular among Muslims, namely the book of al-Syamail Muhammadiyah Imam Tirmidhi. The goal is to reveal the traditions contained in the book from an educational point of view so that it can be a reference in educating future generations to become the next generation. more moral. The research method used is to select the traditions that are adjusted to the themes that are deemed necessary to be discussed and then analyzed and then the results of the analysis are described. The results of this study are that character education is not a new thing, because in the sources of Islamic teachings, one of which is the Qur'an, there are not a few stories from the past that reflect a good personality that is exemplary. The Prophet's mission as a messenger of revelation was to perfect the moral values that were corrupted at that time
\end{abstract}

Keywords : Character Education Values; Kitab Al-Syamail Muhammadiyah Tirmidhi; Personality of The Prophet.

Abstrak. Artikel ini mencoba membahas tentang kepribadian Nabi saw sehari-hari yang dimana terkandung nilai-nilai moral baik yang bisa dicontoh oleh siapa pun. Misalnya bagaimana beliau mengajarkan hidup mandiri, sederhana dan peduli terhadap orang lain. Nilai-nilai moral tersebut diambilkan dari kitab yang begitu popular di kalangan umat Islam yaitu kitab al-Syamail Muhammadiyah Imam Tirmidzi Tujuannya adalah mengungkap hadis-hadis yang terdapat dalam kitab tersebut dari sudut pandang Pendidikan agar bisa menjadi acuan dalam mendidik generasi yang akan datang menjadi generasi yang lebih bermoral. Metode penelitian yang digunakan adalah memilih hadishadis yang disesuiakan dengan tema yang dirasa perlu untuk dibahas lalu kemudian dianalisis selanjutnya hasil Analisa tadi di deskripsikan. Hasil dari penelitian ini adalah bahwasanya pendidikan karakter bukanlah barang yang baru, karena di dalam sumbersumber ajaran Islam salah satunya alQur'an tidak sedikit kisah-kisah orang terdahulu yang menceminkan kepribadian yang baik yang patut dicontoh. Misi Nabi saw sebagai penyampai wahyu adalah menyempurnakan nilai-nilai moral yang rusak pada waktu itu.

Kata Kunci : Pendidikan Karakter; Kitab Al-Syamail Muhammadiyah Tirmidzi; Kepribadian Nabi.

\section{PENDAHULUAN}

Pendidikan karakter menjadi sebuah isu menarik dan hangat di kalangan para pendidik. Maraknya isu ini disebabkan oleh nilai-nilai pendidikan yang dianggap hanya mengedepankan aspek kecerdasan intelektual belaka. Dengan mengesampingkan kecerdasan lain, kecerdasan emosi misalnya. Hal ini yang kemudian melahirkan generasi-generasi cerdas namun masih kurang bisa 
menghargai pendapat orang lain, hilangnya nilai-nilai kejujuran, toleransi, yang kemudian berdampak pada dangkalnya hati nurani dan keluhuran budi. Selain itu, bermunculan anggapan, bahwa pendidikan di Indonesia selama ini hanya melahirkan manusia yang berkarakter hedonis, oportunis, yang tidak memiliki kecerdasan emosi, hati, hingga nurani. Sehingga tidak heran jika terdapat banyak kasus serius yang menimbulkan kerugian terhadap masyarakat, negara, dan lingkungan. Hal yang menyedihkannya adalah, kasus-kasus tersebut justru melibatkan orang-orang yang taraf pendidikannya di atas rata-rata.

Melihat hal tersebut, perlu diadakan penataan terhadap sesuatu yang sudah hilang dan kurang mendapat sentuhan dari dunia pendidikan, yaitu pembentukan karakter. Proses penanaman nilainilai karakter perlu didesain dengan sangat baik dan terstruktur, agar terjadi yang namanya pembentukan karakter. Dalam hal ini, John Sewey mengatakan bahwa pembentukan karakter merupakan tujuan umum Pendidikan budi pekerti di sekolah. Karakter terdiri dari serangkaian sikap, perilaku, motivasi, dan keterampilan. Karakter bukanlah barang yang dapat diwariskan, melainkan harus dibangun dan dikembangkan hari demi hari melalui proses yang tidak instan. Dengan kata lain ia merupakan tanggung jawab pribadi masing-masing (Gunawan, 2012) Lickona menyebutkan setidaknya ada tujuh alasan mengapa harus ada pendidikan karakter; cara terbaik menjamin anakanak memiliki kepribadian yang baik, cara meningkatkan prestasi anak, sebagian siswa tidak dapat membentuk karakternya sendiri tanpa ada yang membimbingnya, agar dapat menyesuaikan dirinya dalam masyarakat yang beragam, berangkat dari masalah yang berhubungan dengan moral-sosial, seperti ketidaksopanan, dan lain sebagainya (Sudrajat, 2011) Melihat kecendrungan studi yang ada tampak bahwa Pendidikan karakter begitu sangat ditekankan kepada setiap masing-masing individu, namun pada prakteknya masih banyak perilaku yang melanggar batas-batas Pendidikan karakter yang diajarkan.

Tulisan ini didasarkan pada argumen, bahwa dalam rangka merealisasikan UU No. 17 Tahun 2007 ialah untuk membentuk jati diri yang kokoh dan karakter bangsa. Tujuan diupayakannya hal tersebut demi terbentuknya manusia yang bertaqwa kepada Allah Yang Maha Esa, taat kepada hukum yang berlaku, hidup rukun antar umat beragama, dan lain sebagainya (Omeri, 2015) Selain itu, Pendidikan karakter tidak akan tersentuh jika hanya sebatas konsep semata tanpa adanya suatu tidakan. Pendidikan karakter adalah sebuah proses yang harus dilakukan secara disiplin dan diterapkan dalam kehidupan nyata sehingga menjadi kebiasaan. Tentunya dalam menanamkan karakter yang baik, dibutuhkan contoh dari seseorang yang memang dianggap berkarakter oleh orang lain. Oleh karena itu dalam tulisan ini diambilkan contoh dari seseorang yang memiliki karakter yang baik yaitu Nabi Muhammad saw. Dengan harapan, terjadinya penataan yang lebih serius akan kemajuan pendidikan karakter ke depan.

Dalam hal ini, penulis bermaksud mengungkap nilai-nilai Pendidikan karakter yang terdapat di dalam kitab al-Syamail Muhammadiyah Imam Tirmidzi. Adapun argumentasi pemilihan kitab ini ialah karena lumayan banyak ulama yang memuji kitab ini. Misalnya komentar dari Syaikh 'Abd al- Rauf alManawi mengatakan bahwa kitab Syamail Muhammadiyah Imam Tirmizi ini merupakan satu-satunya kitab yang riwayatnya teratur dan lengkap. Kemudian komentar dari Ali bin Sulthan al-Qari berkata, "Di antara kitab yang pernah ditulis tentang pribadi dan budi pekerti Rasulullah saw, maka kitab ini adalah kitab yang terbaik, karena disusun dengan ringkas namun padat, sehingga membuat orang yang membaca kitab tersebut dari awal hingga akhir seolah-olah berhadaan dengan Rasulullah." Demikian komentar beberapa ulama dan masih banyak lagi yang lain. Hal ini menunjukkan betapa kredibelnya kitab tersebut untuk dijadikan sumber dalam melihat nilai-nilai Pendidikan karakter yang diajarkan oleh Nabi.

Penelitian ntentang Pendidikan karakter sudah terbilang banyak dikaji oleh para praktisi pendidikan dari berbagai bidang keilmuan. Meskipun demikian, masih belum ada yang mengkaji hadis pendidikan karakter Rasulullah yang terdapat di dalam kitab al-Syamail Muhammadiyah Imam Tirmidzi ini. 


\section{METODE PENELITIAN}

Metode yang digunakan dalam kajian ini ialah kualitatif. Dengan pemahaman analisis konten. Analisis konten adalah salah satu teknik ilmiah untuk memaknai konten ataupun teks. Dalam hal ini, Krippendorff 2004 memaknai analisis konten sebagai teknik penelitian yang akan menyimpulkan makna dari sebuah teks dengan menggunakan prosedur yang terpercaya, dapat diaplikasikan dalam konteks yang berbeda. Dalam analisis konten, terdapat beberapa pendekatan ketika akan melakukan analisis isi, seperti dekripsi, eksplanatif, dan prediktif (Krippendorf, 2004). Kajian dalam penelitian ini akan menitikberatkan pada pendekatan yang deskriptif, karena memang bermaksud mendeskripsikan pendidikan karakter Rasulullah yang terdapat di dalam Kitab al-Samail Muhammadiyah Imam Tirmidzi. Dengan harapan dapat menjadi pembelajaran bagi semua kalangan. Khususnya para praktisi pendidikan dan orang tua. Adapun sumber data primer yang digunakan dalam penelitian ini adalah kitab al-Syamail Muhammadiyah Imam Tirmidzi. Sementara sumberdata sekundernya berupa karya-karya ilmiah, baik jurnal, tesis, ataupun penelitian lain yang sudah pernah dilakukan oleh peneliti sebelumnya. Metode yang digunakan dalam kajian ini ialah kualitatif. Dengan pemahaman analisis konten.

\section{HASIL PENELITIAN DAN PEMBAHASAN}

\section{Hasil Penelitian}

Istilah karakter dalam dunia pendidikan baru digunakan ketika abav 18 akhir. Di mana, terminologinya mengacu kepada pendekatakan idealis spiritualis, yang dikenal dengan teori pendidikan normative. Di mana, yang menjadi fokusnya ialah nilai-nilai transenden yang terpercaya, sehingga bisa menjadi motivasi dan dinamisasi sejarah. Baik itu bagi pribadi seseorang ataupun perubahan social (Ni'matulloh, 2016: 1). Dalam hal ini, Doni A. Kosoema menyatakan, bahwa pendidikan karakter telah dimulai dari Yunani. Yang pada masa tersebut dikenal dengan konsep kepahlawanan bangsa Yunani. Kemudian, adanya konsepsi Socrates yang mulai mengajak manusia mengenal dirinya sendiri, dan juga adanya ilusi pemikiran tentang kebenaran. Lebih lanjut, Doni A menjelaskan historis secara gambling dan menyeluruh tentang pendidikan karakter, yang diurutkan mulai dari homerosi, hoseiodos, Athena, Socrates, Plato, Hellenis, Romawi, Kristiani, Modern, Foerster, dan yang setelahnya (QAnees dan Hambali, 2008: 100).

Dalam pandangan Islam dan berdasarkan sejarah yang panjang, pendidikan karakter adalah misi utamanya para nabi-nabi Allah. Bahkan, Rasulullah sendiri sudah sejak awal mendapatkan tugas untuk menyempurnakan akhlak (karakter) manusia. Tugas utama Rasulullah ini kemudian menjadi bukti atau petunjuk bahwa karakter adalah kebutuhan yang paling utama bagi settiap manusia. Lebih lanjut, ia juga menjadi kebutuhan akan tumbuh kembangnya cara beragama sehingga bisa menciptakan sebuah peradaban. Sementara di sisi yang lain, hal ini juga menunjukkan, bahwasanya setiap jiwa tentu mempunyai karakternya masing-masing yang memang perlu disempurnakan. ( QAnees dan Hambali, 2008: 100).(Fattah, 2017).

Secara bahasa, kata karakter dapat diartikan sebagai sifat kejiwaan, tabiat, akhlak, budi pekerti, dan watak yang akan membedakan antara yang satu dengan yang lain (Hamid dan Sabeni, 2013: 31). Sementara secara istilah, karakter merupakan sifat manusia pada umumnya yang tergantung dengan faktor kehidupannya sendiri (Fitri, 2012) Pendidikan karakter sendiri bisa diartikan dengan banyak sudut pandang. Dalam hal ini, Lickona memaknai pendidikan karakter sebagai usaha dalam menanamkan karakter atau nilai-nilai kepada seluruh keluarga atau warga sekolah. Yang di dalamnya mencakup pengetahuan, tindakan, dan kesadaran dalam menerapkan nilai-nilai tersebut, baik penerapannya terhadap Tuhan, pribadi, hingga lingkungan dan masyarakat.(Lickona, 1996) Selain Lickona, masih ada banyak tokoh lain yang juga berbicara tentang pendidikan karakter. Seperti Elkind D.H \& Sweet F(Sweet), dan Harta. Elkind D.H \&Sweet berpendapat bahwa pendidikan karakter merupakan segala hal yang dilakukan oleh tenaga didik yang bisa mempengaruhi perilaku dan sikap peserta didiknya. Yang di dalamnya terdapat 
keteladanan seorang guru(Sweet), cara guru menyampaikan dan berkomuniksasi, bagaimana seorang guru bertoleransi, dan lain sebagainya. Harta berpendapat, bahwa pendidikan karakter bukanlah sebatas pengajaran benar dan salah, melainkan bisa menanamkan kebiasaan, hingga anakanak bisa memahami mana yang baik dengan yang buruk. Dan mampu merasakannya (Harta).

Menurut Koesoema (2012: 57) pendidikan karakter merupakan upaya dalam mengembangkan seluruh dinamika relasional antar pribadi yang berasal dari berbagai dimensi. Baik yang berasal dari dalam ataupun dari luar. Sehingga, agar tercipta pribadi yang menghayati kebebasannya, ia akan bertanggungjawab atas perkembangan dan pertumbuhan dirinya dan orang lain yang berdasarkan dengan moral. Secara akademis, pendidikan karakter diartikan sebagai pendidikan budi pekerti, pendidikan nilai, pendidikan moral, pendidikan akhlak, pendidikan watak, yang bertujuan utuk mengembangkan kemampuan para anak didik dalam mengambil keputusan baik-buruk, mengerti konsep kebaikan, kemudian mewujudkannya dalam berkehidupan dengan rasa ikhlas dan sepenuh hati. Sehingga, muatan dari pendidikan karakter akan mencakup berbagai dimensi, seperti moral feeling, moral reasoning, hingga moral behavior. Sementara secara praktisnya, pendidikan karakter merupakan system penanaman nilai kebaikan kepada seluruh warga sekolah dan kampus, yang di dalamnya terdapat komponen, seperti pengetahuan, kesadaran dan kemauan, hingga tindakan demi terlaksananya nilai-nilai kebaikan tersebut, baik itu hubungannya dengan Tuhan, dengan semama manusia, lingkungan, atau yang lainnya hingga benar-benar menjadi manusia paripurna (insan kamil). (Marzuki, 2010: 2-3) (Rudiana, 2015).

Ibnu faris menyebutkan, bahwa konsep Pendidikan dalam Islam adalah membimbing seseorang sembari memperhatikan segala potensi yang ia miliki. Melalui langkah-langkah yang sesuai sebagai sarana untuk mendidik jiwa, akhlak, akal pikiran, fisik, agama, dan lain sebagainya. Hal demikian melahirkan konsep pendidikan yang sangat komprehensif, di mana hasilnya adalah terjadinya keseimbangan hubungan dirinya dengan Tuhannya, hubungan dengan sesama manusia dan terakhir hubungan dengan alam sekitarnya. Selain itu, Al-Ghazali juga menawarkan sebuah konsep pendidikan. Menurutnya, seberapa dekat seseorang dengan Tuhannya adalah sebaga tolak ukur kesempurnaan dirinya, yang menjadi sarana agar ia dapat dekat dengan Tuhannya adalah Ilmu pengetahuan(Ainiyah, 2013)Tidak jauh berbeda dengan pendapat di atas, Ki Hadjar Dewantara juga memiliki konsep Pendidikan yang ia istilahkan dengan Tri Pusat Pendidikan yaitu, sekolah, keluarga dan masyarkat. Adalah sebuah keniscayaan bahwasanya Pendidikan tidak hanya berfokus di sekolah saja, melainkan juga adanya keikutsertaan peran keluarga dan masyarakat sekitarnya. Hal demikian dapat membantu kesuksesan dalam membangun karakter yang diharapkan. Selain konsep ini, Ki Hadjar Dewantara juga memiliki konsep yang lain yaitu tutwuri handayani dan tringgo (ngerti, ngroso, nglakoni). Ki Hadjar Dewantara menjadikan tutwuri handayani sebagai semboyan dalam sistem pendidikannya. Menurut Sudarto yang mengutip pendapat Ki Soeratman bahwasanya sikap tutwuri adalah suatu perilaku dari seorang pendidik yang sifatnya memberikan kebebasan kepada siswa untuk berbuat sesuatu sesuai dengan apa yang dikehendaki olehnya, selama tidak melampui norma-norma yang berlaku dan tidak menimbulkan kerugian bagi orang lain (Wardani, 2010). Mengutip pernyataan dari Russel Williams, ia menggambarkan karakter seperti sebuah otot yang harus terus menerus dilatih agar menjadi otot yang kuat, sebaliknya otot akan menjadi lemas jika tidak terus-menerus dilatih. Begitu juga dengan karakterse seorang, dia akan terbentuk di dalam kehidupannya sehari-hari bilamana terus-menerus dipraktikkan dalam kehidupan sehari-hari sehingga menjadi sebuah kebiasaan. Pendidikan karakter tidak akan berhasil jika hanya sebatas teori yang hanya diajarkan saja. Sesuai dengan pernyataan-pernyataan sebelumnya bahwasanya hakikat dari Pendidikan karakter sendiri adalah terciptanya sebuah keseimbangan antara seseorang hamba dengan Tuhannya, keseimbangan seseorang dengan orang yang ada di sekitarnya serta kesimbangan antara ia dengan alam sekitarnya. Terciptanya keseimbangan-keseimbangan tersebut harus ada kerjasama yang diistilahkan oleh Ki Hadjar Dewantara sebagai tri pusat Pendidikan tadi, yaitu keluarga, sekolah, maupun masyarakat. 


\section{Pembahasan}

Dari berbagai pendapat di atas, dapat disimpulkan bahwa pendidikan karakter mempunyai peranan yang sangat penting dalam membentuk karakter seseorang.

\section{Adapun Beberapa Karakter Rasulullah}

Setelah melakukan penelitian dengan cara memperhatikan karakter Rasulullah, maka penulis mendapati 5 karakter Rasulullah. Yaitu mandiri, pemurah, sederhana, tawwadhu'. Meskipun sebenarnya, jika kita kaji sejarah, maka nyaris segala karakter baik itu terdapat di dalam diri beliau. Sebab, Rasulullah adalah suri tauladan yang paling baik. Sebagaimana yang telah dijelaskan di dalam al-Quran. Namun, karena memang kajian ini difokuskan pada 'kitab al-Syamail Muhammadiyah', sehingga penulis hanya perlu memaparkan karakter yang terdapat di dalam kitab al-Syamail Muhammadiyah saja. Maka, ketika karakter-karakter Rasulullah tersebut digambarkan, maka bentuknya akan seperti,

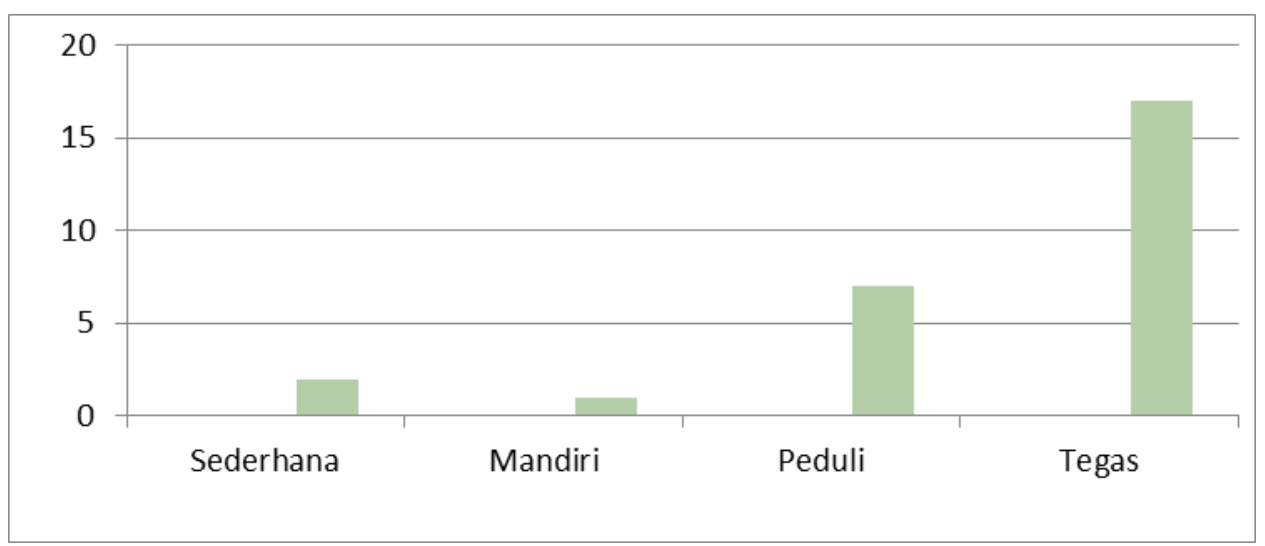

1. Mandiri

Di dalam kitab al-Syamail Muhammadiyah Imam Tirmidzi, terdapat 1 hadis yang menggambarkan bahwa Rasulullah adalah sosok yang mandiri. Hadisnya berdasarkan cerita dari 'Amrah.

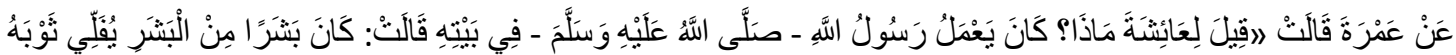

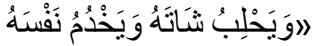

'Aisyah ra. Ditanya, 'Apa yang dilakukan oleh Rasulullah ketika di rumah?' Lalu 'Asiyah menjawab, 'beliau adalah seorang manusia biasa, beliau adalah orang yang mencuci bajunya sendiri, memerah susu kambingnya sendiri, dan melayani dirinya sendiri' (Saurah, 1986).

Dalam hadis tersebut, dijelaskan bahwa 'Rasulullah merupakan manusia biasa. la menanggalkan pakaiannya sendiri, memerah susu domba-dombanya sendiri, hingga melayani dirinya sendiri. Hal ini menunjukkan bahwa Rasulullah adalah seseorang yang mandiri. Dengan pangkat kenabiannya tidak lantas menjadikan Rasulullah ingin dilayani oleh para sahabatnya, meskipun hal tersebut bisa saja terjadi. Desmita(Desmita, 2009 ) menyatakan, bahwa kata 'kemandirian atau mandiri' mempunyai beberapa maksud. Seperti kondisi di mana seseorang mempunyai hasrat bersaing dengan orang lain agar bisa menjadi lebih baik. Kedua, bisa mengambil keputusan sendiri dan mempunyai inisiatif dalam menghadapi berbagai masalah. Ketiga, mempunyai kepercayaan diri dalam menyelesaikan segala tugas-tugasnya tanpa meminta bantuan orang lain. Kelima, bertanggungjawab atas segala tindakan yang telah diambil.

Sementara itu, Mustari (Mustari, 2011) mengemukakan pendapat, bahwa mandiri merupakan sikap serta perilaku yang tidak gampang bergantung kepada orang lain dalam menyelesaikan tugastugasnya. Dari kedua pendapat tersebut, bisa ditarik kesimpulan, bahwa indicator kemandirian seseorang bisa dilihat dari beberapa aspek. Seperti seberapa besar hasratnya untuk bersaing, 
seberapa besar kepercayaan diri, tanggung jawab, dan kemampuan dalam menghadapi dan memutuskan sebuah permasalahan yang ada.

Karakter ini ternyata memicu datangnya komentar baik. Salah satunya adalah komentar yang dilontarkan oleh seorang Sejarawan Barat yang terkenal. Namanya adalah Edward Gibbon (Gibbon, 1776). la merupakan salah satu orientalis terkenal dan terkemuka pada masa Renaissance. Di dalam bukunya, dia mengatakan, 'Hal baik yang ada di dalam diri Muhamamd adalah, beliau menjauhkan kcongkakan seorang raja. Rasulullah itu melakukan pekerjaan yang kasar di rumahnya. Menyalakan api, menyapu lantai, memerah susu sapi, dan memperbaiki sepatu dan baju-bajunya sendiri. Dalam hal ini, 'Aisyah juga pernah ditanya mengenai apa saja yang dilakukan Rasulullah sehari-hari. la menjawab, bahwa Rasulullah mencuci bajunya sendiri, memerah susu kambing, dan mengurus dirinya sendiri.'

\section{Sederhana}

Karakter berikutnya adalah sederhana. Hadis tentang karakter sederhana ini berasal dari Anas bin Malik yang berbunyi,

ان رسول اله ص.ل حج عل رحل رث وقطيفة كنا نر ثمنها اربعة در اهم فلما استوت به راحلته قال: لبيك بحجة لا سمعة فيه ا ولارياء

Rasulullah pergi melaksanakan ibadah haji. Beliau duduk di atas pelana unta yang telah using dan memakai selimut murahan yang kami kira harganya Cuma empat dirham. Taqtkala kendaraannya telah siap berangkat, beliau berdoa: 'Labbaika bi hajjatin la sum'ata fiha wa la riya (Kupenuhi panggilan Mu ya Allah untuk melaksanakan haji yang tiada riya' dan sum'ah padanya).

Diriwayatkan oleh Ishaq bin Manshur dari Abu Dawud al-Thayalisi dari Rabi' bin Shabih dari Yazid al-Raqasyi yang bersumber dari Anas bin Malik (Saurah, 1986). Di dalam buku ini, ada beberapa hadis yang berbicara tentang kesederhanaan Rasulullah. Yang mana, karakter tersebut nyaris bertolak belakang dengan karakter masyarakat urban saat ini. Rasulullah terbiasa menahan lapar, dan hanya makan sekadarnya saja. Bahkan sepeninggalakan beliau, para sahabtnya kerap menangis saat berada di depan hidangan yang lezat-lezat. Sebab mereka terkenang akan karakter Rasulullah. Kesederhanaan Rasulullah bahkan bukan hanya digambarkan pada sikapnya yang makan ala kadarnya. Melainkan banyak potret atau gambaran karakter sederhana yang ditunjukkan Rasulullah. Dan hal tersebut akan membuat kita kagum sepanjang hidup. Karakter sederhana ini seolah sudah mendarah daging di dalam diri Rasulullah, karena setiap lini kehidupannya dipenuhi dengan kesederhanaan. Beliau sederhana dalam berpakaian. Tempat tidurnya bahkan sangatlah sederhana. Beliau sering berpuasa. Karakter sederhana ini akhirnya menjadi memori tersendiri bagi setiap orang. Bahkan, pernah di suatu hari, tatkala Rasulullah dengan rombongan melakukan perjalanan yang cukup jauh. Tatkala mereka berhenti, ada seorang sahabat yang memutuskan untuk menyembelih domba untuk diolah. Kemudian mereka sepakat untuk membagi-bagi tugas. Ada yang menyembelih domba, menguliti, dan memasak. Dalam keadaan seperti itu, Rasulullah tidak kebagian tugas. Beliau lantas berkata, 'Aku akan ikut mengumpulkan kayu bakar.' Sahabat Rasulullah kemudian berkata lagi, 'Wahai Rasulullah, biarkan kami saja yang melakukannya.' Rasulullah justru menjawab, 'Aku tahu kalian bisa melakukannya. Tapi aku juga tidak ingin diperlakukan secara istimewa di antara kalian.'

Sangat jelas, bahwa beliau mempunyai karakter sederhana yang sangat luar biasa dan pasti tidak akan ada tandingannya. Hadis ini juga mengungkapkan, betapa sederhannya hidup beliau. Dan bertolak jauh dengan gelar dan jabatan yang diembannya. Kalimat akhir yang diungkapkan Rasulullah menjadi gambaran paling jelas, bahwa beliau sangatlah sederhana. Bahkan tidak ingin diperlakukan secara sederhana meskipun beliau adalah Nabi, Rasul, imam besar, seorang orator ulung, kepada pemerintahan. Di dalam buku Histoire e la Turqui karya Lamertine, disebutkan bahwa bahwa Rasulullah adalah soerang penakhluk. Bukan hanya itu saja. Rasulullah juga toko Quraisy yang sangat disegani. Dengan segala jabatan dan pangkatnya sama sekali tidak membuat beliau menginginkan kehidupan yang lebih dari cukup. Bahkan kadang terkesan kekurangan. Karena terdapat hadis yang 
diriwayatkan oleh Aisyah, bahwa kadang-kadang hingga sebulanan penuh terlewati tanpa adanya nyala api di dapur. Kami hanya hidup dengan kurma dan juga air putih. Maka, pembahasan seputar kesederhanaan Rasulullah tidak akan pernah mencapai puncak. Karena memang setiap sisi kehidupan beliau adalah kesederhanaan. Tidak dipungkiri, bahwa karakter inilah yang sulit untuk ditemukan pada masyarakat masa kini.

3. Peduli

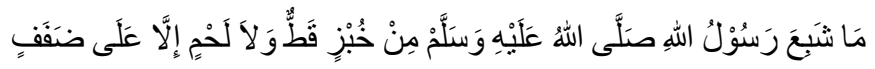

Rasulullah saw tidak pernah kenyang makan roti, dan tiada pula dengan daging, kecuali dalam keadaan dlaffaf. Malik bin Dinasr selanjutnya berkata, "aku bertanya kepada seorang laki-laki dari pedusunan, 'apa yang dimaksud dengan dlaffaf ?', ia menjawab, 'makan bersama orang banyak."

Peduli merupakan sikap memperlakukan orang lain dengan baik, sopan, bertindak santun, tidak menyakiti orang lain, toleran, tidak mengambil keuntungan dari orang lain, mneyayangi manusia dan juga makhluk yang lain, terlibat dalam berbagai macam kegiatan kemasyarakatan, hingga cinta akan kedamaian ketika menghadapi berbagai macam persoalan (Eko, 2011). Zuchdi menyatakan, bahwa peduli merupakan tindakan dan sifat yang terus menerus ingin memberikan bantuan kepada orang lain yang memang membutuhkan (Zuchdi, 2011). Maka, ketika berbicara mengenai kepedulian social, tentu tidak akan bisa melepaskan diri dari kesadaran social. Kesadaran ini adalah kemampuan dalam memahami makna situasi dan kondisi social. Sehingga, akan sangat bergantung dengan bagaimana dan seperti apa empati terhadap orang lain. Dengan demikian, dapat dikatakan bahwa peduli adalah keinginan besar untuk menolong orang lain yang didorong oleh kesadaran (Malik, 2008). Melihat hal tersebut, tentu karakter ini sudah sangat melekat di dalam diri Rasulullah. Bahkan, sikap kepedulian Rasulullah bukan hanya tergambar dalam hadis tersebut. Melainkan masih banyak contoh kepedulian lainnya. Salah satunya adalah kisah yang sudah terekam jelas di dalam benak anak-anak generasi 90-an. Di mana, kisah ini bercerita tentang Rasulullah dengan laki-laki buta. Dengan rasa kepedulian yang tinggi, beliau rutin memberikan makan lelaki buta tersebut, meski ketika sedang 'disuapi' beliau mendapatkan cacian terhadap beliau. Namun, karakter peduli yang tertanam di dalam diri beliau akhirnya membuat beliau tidak lagi mempedulikan cacian terhadap dirinya.

Maka, apabila karakter peduli ini ditelisik lebih jauh pasti tidak akan ada ujungnya. Dalam menumbuhkan karakter peduli, tentu ada berbagai langkah yang meski dilakukan. Salah satunya adalah membiasakan diri untuk menolong orang lain dengan kesadaran penuh. Selain itu, pembahasan terkait karakter peduli ini juga tergambar dalam hadis,

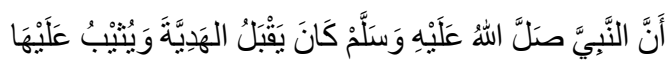

Sesungguhnya Nabi saw. Menerima hadiah dan membalas hadiah.

Apabila seseorang memberikan sesuatu kepada orang lain, dengan tidak bermasuksud menerima balasan, maka hukumnya adalah boleh atau mubah. Hal ini sebagaimana yang telah dijelaskan dalam hadis, yang diriwayatkan Imam Bukhari dari Istri Rasulullah, Aisyah ra. Telah menceritakan kepada kami Musaddad, telah menceritakan kepada kami Isa bin Yunus, dari Hisyam dari ayahnya dari Aisyah, ia berkata: Rasulullah menerima hadis kemudian membalas hadis tersebut dengan balasan yang serupa. Hadis tersebut menyatakan, bahwa ketika Rasulullah menerima 'hadiah', beliau akan memberikan balasan yang sama. Dalam hal ini, terdapat ulama yang menyatakan, bahwa seseorang tidak boleh menolak hadiah yang diberikan oleh orang lain. Dan yang menjadi landasannya adalah hadis yang diriwayatkan oleh Imam Bukhari, al-Tirmidzi. Di mana keduanya diriwayatkan dari Abu Hurairah, bahwa Rasulullah telah bersabda, 'Menceritakan kepada kami Muhammad bin Basyar, telah menceritakan kepada kami Ibnu Abi Adi, dari Syu'bah, dari Sulaiman, dari Abi Hazim, dari Abu Hurairah, dari Rasulullah, beliau telah bersabda, jika aku diundang 
untuk menyantap kaki kambing (depan dan belakang), maka akan kupenuhi dan jika sekiranya diahdiahkan kepadaku kaki kambing, maka aku akan menerimanya (2017). Tindakan ini dilakukan ketika seseorang mendapatkan hadiah dari orang lain. Hal ini senada dengan firman Allah di dalam beberapa surah. Karena sejatinya, ketika seseorang mendapatkan kebaikan, maka ada baiknya jika bisa membalas kebaikan tersebut. Sebagaimana yang telah disebutkan Allah dalam firman Nya.

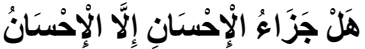

"Tidak ada balasan kebaikan kecuali kebaikan (pula)." (Ar-Rahman: 60)

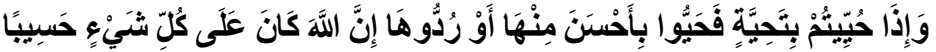

"Apabila kamu diberi penghormatan dengan sesuatu penghormatan, maka balaslah penghormatan itu dengan yang lebih baik dari padanya, atau balaslah penghormatan itu (dengan yang serupa). Sesungguhnya Allah memperhitungkan segala sesuatu. (An-nisa: 86)

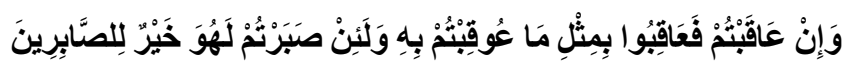

"Dan jika kamu memberikan balasan, maka balaslah dengan balasan yang sama dengan siksaan yang ditimpakan kepadamu. Akan tetapi jika kamu bersabar, sesungguhnya itulah yang lebih baik bagi orang-orang yang sabar. (An-Nahl : 126)

Pengetahuan akan 'karakter' yang terdapat di dalam diri Rasulullah merupakan sebuah keniscayaan. Karena pengetahuan ini akan menjadi contoh dan tauladan dalam kehidupan seharihari. Khususnya di dunia pendidikan. Apalagi mengingat, bahwa tujuan penciptaan Rasulullah ke muka bumi adalah untuk memperbaiki akhlak manusia.

\section{KESIMPULAN}

Dalam Islam, pendidikan karakter bukanlah hal yang baru. Sebab di dalam sumber hukumnya terdapat banyak kisah dan pelajaran tentang karakter. Salah satu contohnya dalam al-Quran adalah perintah untuk membalas kebaikan dengan yang kebaikan yang lebih baik. Sementara dalam hadis, terdapat berbagai macam karakter yang terdapat di dalam pribadi Rasulullah. Seperti mandiri, peduli, sederhana, dan tegas. Di mana, dengan pengetahuan karakter yang terdapat di dalam diri Rasulullah menjadikan spirit untuk berbuat lebih banyak, dan berlomba-lomba dalam mengaplikasikannya. Sehingga tujuan atau misi penciptaan Rasulullah berhasil.

\section{DAFTAR PUSTAKA}

Ainiyah, N. a. (2013). Pembentukan Karakter Melalui Pendidikan Agama Islam. Al-Ulum .

Desmita. (2009 ). Psikologi Perkembangan Peserta Didik. Bandung: PT Remaja.

Eko, H. (2011). Character Buildding for Teens . Yogyakarta: Leutikaprio.

Fitri, A. Z. (2012). Reinventing Human Character: Pendidikan Karakter Be rbasis Nilai \& Etika di Sekolah. Jogjakarta : Ar-Ruzz Media.

Gibbon, E. (1776). History of The Decline and Fall of the Roman Empirer.

Gunawan, I. (2012). Pendidikan Karakter. Bandung Alfabeta.

Harta. (n.d.). Pengintegrasian Pendidikan Karakter dalam Pembelajaran Matematika SMP/MTs. 
Krippendorf, K. (2004). Content Analysis: an Introduction to Its Methodology. London: Sage Publications.

Lickona. (1996). Eleven Priciples of Effective Character Education. Journal of Moral Education , 93100.

Malik, H. L. (2008). Pendidikan Anak SD. Jakarta: Universitas Terbuka.

Mustari, M. (2011). Nilai Karakter. Yogyakarta: LaksBang PRESSindo.

Omeri, N. (2015). Pentingnya Pendidikan Karakter dalam Dunia Pendidikan. ejournal.unib.ac.id .

Saurah, A. I. (1986). al-Syamail al-Muhammadiyah . Bandung: CV Penerbit Diponegoro.

Sudrajat, A. (2011). Mengapa Pendidikan KarakterJurnal Pendidikan Karakter . https://doi.org/10.21831/jpk.v1i1.1316.

Sweet, E. D. (n.d.). How to do Character Education.

Tanjung, I. (2017). Pemberian Hadiah Kepada Pegawai: Tinjauan Hukum Islam dan Undang-Undang Republik Indonesia Nomor 20 Tahun 2001 . AT-TAFAHUM: Journal of Islamic Law , 72-85.

Wardani, K. ( 2010). Peran Guru dalam Pendidikan Karakter Menurut Konsep Pendidikan KI Hadjar Dewantara. "proceedings of the 4th international conference on teacher education; join conference UPI \& UPSI BANDUNG.

Zuchdi, D. (2011). Pendidikan Karakter dalam Prespektif. Yogyakarta: UNY Press. 